\title{
GREEN INFRASTRUCTURE: IMPLICATIONS FOR SPATIAL, LAND USE AND TRANSPORTATION PLANNING
}

\author{
C.B. SCHOEMAN \& I.M. SCHOEMAN \\ Unit for Environmental Sciences and Management (Potchefstroom Campus) and \\ Unit for Business Mathematics and Informatics, North West University (NWU), South Africa
}

\begin{abstract}
The concept of green infrastructure (GI) development is promoted worldwide within planning of urban spatial systems. It implies the application of resilience and sustainability considerations in spatial and more specifically transportation planning.

The purpose of this article is to assess the linking of incentives to promote green infrastructure development through transdisciplinary planning processes by integrating and mainstreaming related disciplines and planning in general. Spatial planning traditionally deals with specific instruments and methodologies focussing on developing the natural, socioeconomic and built environment. Transportation planning, due to its integration with land use planning, focuses on movement systems and implies intra- and intermovement of people, goods and services supporting development and growth in urban spatial systems.

In decision-making for statutory planning, the impact of development is used to levy service contributions in urban areas. It includes the calculation of financial contributions to access conventional infrastructure services networks in terms of specific development policies and priorities. Limited incentives exist to promote, integrate and mainstream green development practices in land use and transportation planning.

Linking and alignment of GI to brown and grey space planning and development processes is essential to promote inclusivity in ecosystem service (ES) attainment. This goal and objective requires development contribution policies inclusive of equitable incentives to promote green planning approaches and principles in planning processes. It implies application of alternative transdisciplinary practices in spatial planning, urban design, transportation and the provision of infrastructure in general.

Development goes beyond the limits of an individual discipline, site, neighbourhood, town, region or any related spatial and/functional entity and should be linked to system-wide approaches to enhance and integrate ES development in a transdisciplinary way. In attaining this challenge, spatial and transportation planning processes have an important role to fulfil.
\end{abstract}

Keywords: development contributions, green infrastructure, transdisciplinary mainstreaming, transportation systems, transportation technology.

\section{INTRODUCTION}

Planning in the 21 st century is directed by system development, densification and transformation influences due to complexities and dynamics within spatial systems. More emphasis is placed on balancing and offsetting traditional 'grey spaces' and 'green spaces' in terms of spatial planning, transportation and development. This implies the need for a paradigm shift in the application of development contributions based on land use planning and authorizations within urban areas. This statement directly links to the need and focus for green development [1] and sustainable cities [2]. The challenge is further complicated by the reality to ensure that all spatial and transportation planning is undertaken in the context of resilience and sustainability principles in terms of design, implementation, operation and management processes.

This article is a continuation of the line of argument as developed in the paper on Theoretical Perspectives on Resilience and Sustainability in Transportation and Spatial Planning in 
2017 [3]. It now also considers the context of ecosystem services (ESs) and how it is articulated through different planning instruments. Cortinovis and Geneletti [4] states that land use decisions made during planning processes determine the availability and well-being of urban population. They further conclude that the inclusion of ESs in planning is essential to promote sustainable urban development.

Fundamental in this is the role of decision-making in land authorizations in terms of land use schemes and/or statutory land regulation mechanisms by optimizing green infrastructure (GI) provision. It needs to integrate spatial, transportation, environmental, infrastructure and land use management activities through transdisciplinary planning teams. Land authorizations are based on planning instruments such as spatial development frameworks, environmental impact assessments, statutory planning (township establishment and rezoning processes), traffic impact assessments, engineering infrastructure and service development reports and related sectoral planning instruments. The linkage between such instruments depends on collective application of GI principles in promoting ES development.

Cilliers and Cilliers [5] point out that it is challenging to integrate spatial planning and GI in urban contexts where land use decisions (inclusive of spatial planning) have to address the demand for housing and other services. Mell [6] conclude that GI is grounded in global literature but that greater variety is evident in its application on different scales (national, regional and subregional). The planner needs to facilitate, educate and advocate the financial and technical capacity related to GI application benefits. This article is an endeavour to assess this interface between planning instruments/processes in the context of ES enhancement through application of GI within spatial systems.

\section{GREEN INFRASTRUCTURE CONTEXT AND IMPLICATIONS}

Ranjha [7] points out that cities are an important habitat for an array of physical, economic, social, political and cultural capital. The nature, operation and form of cities particularly in respect to the challenging issue of sustainability and resilience (refer to [3]) thus implies a particular spatial challenge to planning and development amongst planning practitioners and other disciplines.

Cities are facing problems such as biodiversity and natural habitat loss, air pollution exceeding safe limits, urban flooding and droughts due to the absence of integrated spatial planning and development processes. Urbanization is driven by factors such as population growth, increasing demand for space to accommodate modern urban facilities and the implication of increased demand in the provision of internal and bulk infrastructure services (inclusive of transportation systems). This phenomenon requires the optimization of planning processes to deal with such dynamics [7]. This planning challenge is the result of the non-alignment of environmental and spatial planning theories and processes, ad hoc service provision, lack of integrated design and implementation practices [3]. GI is globally recognized as an essential component of liveable and sustainable places. It brings together land uses, urban design and functional features (built environment) at various scales [8]. It thus implies the need for transdisciplinary in planning and development practices.

\subsection{Definition and approach to green infrastructure planning}

According to the United States Environmental Protection Agency (EPA), GI is associated with a variety of environmental, economic and human health benefits, many of which go 
hand in hand with one another. The benefits of GI are particularly accentuated in urban and suburban areas where green space is limited and environmental damage is more extensive [9]. In the context of the theme of this article, the following two definitions of GI applies:

Green infrastructure thinking and planning brings together planning, natural resource, ecological, and sustainable development concepts to provide a systems approach to infrastructure planning and development that recognizes the value of ESs, and integrates those ESs within the built environment. Most importantly and less well acknowledged is that green infrastructure is not limited to the physical outcome; it includes the process through which a broad network of institutions, organization, agencies, businesses and citizens bring ESs back into planning value systems and actively direct more sustainable development. [10].

The European Commission (EC) developed the following definition for GI:

Green infrastructure is a strategically planned network of natural and semi-natural areas with other environmental features designed and managed to deliver a wide range of ESs such as water purification, air quality, space for recreation and climate mitigation and adaptation [11].

GI planning is thus a common denominator to enhance environmental, economic and social benefits through natural solutions and assists in reducing dependency on 'grey' infrastructure that is often more expensive to build and maintain. In this context, some of the benefits of GI application are shown in Table 1.

In promoting the application GI, the need for mainstreaming actors at various levels and scales through green planning initiatives is central in focus (e.g. regionally, urban or neighbourhood level). This scale reality is applicable to all planning undertaken and can only be attained through application of transdisciplinary planning processes. The Centre for Leadership in Global Sustainability (CLGS) [10] states that infrastructure supports our lives and livelihoods and manages our access to food, water, energy, transportation, communication, waste disposal and other critical services and functions. It provides the foundation on which communities (urban and rural), economy and security are built, thrive or falter.

The consideration of resilience and sustainability by various disciplines involved in environmental, spatial, land use, transportation and infrastructure system planning is thus fundamental. It directly correlates to the status and strength of urban, rural and regional entities (spatial systems at different scales). The provision of infrastructure is taken for granted until such systems fail or the cost of maintenance becomes exorbitant [10]. Mounting investments required to repair and maintain aging stock of grey infrastructure and increasing environmental pressures from expanding urbanization, considering the value of ESs that have otherwise been 'free', are entering more prominently in planning and infrastructure debates amongst all disciplines.

This reality is compounded by the increasing regulatory pressure to address water and air quality (pollution), impacts of traffic congestion, the need to anticipate and adapt for localized impacts of climate change and the drive for economic competitiveness and sustainability. It is further complicated by restricted finances and resources for all communities, cities and regions across all spatial systems and involves various disciplines. The CLGS concludes 
Table 1: Some focuses and benefits of GI in development.

\begin{tabular}{|c|c|c|}
\hline Green infrastructure* & $\begin{array}{l}\text { Grey/brown spaces and the } \\
\text { built environments* }\end{array}$ & Transportation* \\
\hline $\begin{array}{l}\text { Reduced and delayed storm } \\
\text { water runoff volumes }\end{array}$ & $\begin{array}{l}\text { Water flow regulation and } \\
\text { flood control }\end{array}$ & Permeable pavements \\
\hline $\begin{array}{l}\text { Enhanced groundwater } \\
\text { recharge }\end{array}$ & $\begin{array}{l}\text { Water purification } \\
\text { On-site primary sewerage } \\
\text { purification }\end{array}$ & Bio-swales \\
\hline $\begin{array}{l}\text { Storm water pollution } \\
\text { reductions }\end{array}$ & $\begin{array}{l}\text { Reduce grey/brown infra- } \\
\text { structure costs }\end{array}$ & Planter boxes \\
\hline $\begin{array}{l}\text { Reduced sewer overflow } \\
\text { events }\end{array}$ & $\begin{array}{l}\text { Use of alternative building } \\
\text { materials }\end{array}$ & Landscaping \\
\hline $\begin{array}{l}\text { Increased carbon } \\
\text { sequestration }\end{array}$ & $\begin{array}{l}\text { Application of alternative } \\
\text { construction technology }\end{array}$ & Permeable road shoulders \\
\hline $\begin{array}{l}\text { Urban heat island } \\
\text { mitigation }\end{array}$ & $\begin{array}{l}\text { On-site waste water } \\
\text { pre-treatment }\end{array}$ & $\begin{array}{l}\text { Infiltration trenches, basins } \\
\text { and galleries }\end{array}$ \\
\hline $\begin{array}{l}\text { Reduced energy demands } \\
\text { Application of renewable } \\
\text { energy sources }\end{array}$ & Rain water retention & $\begin{array}{l}\text { Bioretention with draining } \\
\text { systems }\end{array}$ \\
\hline Improved air quality & $\begin{array}{l}\text { On-site waste water } \\
\text { pre-treatment }\end{array}$ & Media filter drains \\
\hline $\begin{array}{l}\text { Additional wildlife habitat } \\
\text { and recreation space }\end{array}$ & Solid waste recycling & $\begin{array}{l}\text { Emission reduction policy } \\
\text { non-motorized transport }\end{array}$ \\
\hline Improved human health & Increased property values & Land use and ecology \\
\hline Increased land values & Enhanced marketability & $\begin{array}{l}\text { Improved energy utilization } \\
\text { (EVs) promotion of public } \\
\text { transport }\end{array}$ \\
\hline Income generation & Green building design & $\begin{array}{l}\text { Green road systems and } \\
\text { corridors }\end{array}$ \\
\hline Green planning promotion & Lower operating costs & $\begin{array}{l}\text { Alternative pavement } \\
\text { designs }\end{array}$ \\
\hline
\end{tabular}

Source: Own construction, 2017. * Rows not organized thematically.

that due to this, it requires assigning a higher priority in the application GI systems in planning and thus the notion of mainstreaming and integration.

Albert and Von Haaren [12] points out that the concept of GI should be linked to ESs based on the work of the EC. The merit of following the concept is that it overcomes the limitation of the term 'infrastructure' to a technical focus and includes natural phenomena. They point out that the ES approach assesses the value of services provided to society by the natural environment: 'Identification, assessment, quantification and, sometimes, economic valuation of ES provision should enhance public awareness and contribute to the long-term protection and sustainable use of biodiversity and other natural resources'. 
The concept of ES differs from GI in that it includes an approach to illustrate the dependency of human well-being on ecosystem capacity to provide essential services. At the same time, GI represents a strategy for safeguarding or enhancing the provision of ES. In this context, the GI concept represents more than the traditional idea of multifunctional planning and development in that it has stronger emphasis on the concept of ES and in delivery to society. It implies also that GI renders improved communication, integration and mainstreaming of its benefits of conservation and sustainable use of natural resources. GI also connects to the notions of resilience, ecosystem health and biodiversity conservation [12].

The research by Albert and Von Haaren [12] includes the development of a matrix of levels of priority for GI development for certain types of areas. Data, indicators and methods are used for assessing selected ES such as habitats, natural yields, climate change mitigation, local climate, groundwater recharge and visual landscape. The longer-term benefits of preserving a distinctive landscape character for the provision of cultural ES may be undervalued against shorter-term economic interests in promoting commercial development. It thus illustrates the need for integration and mainstreaming in planning processes through transdisciplinary planning processes.

\subsection{Integration, alignment and mainstreaming perspectives}

Hansen and Pauleit [13] point out that GI and ES are promoted as concepts that have the potential to improve environmental planning in urban areas based on a more holistic understanding of the complex interrelations and dynamics of social-ecological systems. They further state that the scientific discourses around both concepts still lack application-oriented frameworks to consider it in a holistic perspective that are suitable to mainstream GI and ES in planning practice. The research reports in detail on the literature review that explores multifunctionality as one important principle of GI planning and that can be operationalized by approaches developed and tested in ES research. ES research and application may assist in determining the integrity of GI networks, to balance ES supply and demand and to consider alternative trade-offs.

This supports the view as contained in Albert and Von Haaren [12]. It provides for a conceptual framework to assess multifunctionality from a social-ecological perspective that may inform the design of planning processes and support stronger exchange between GI and ES research [13]. The following organizational and integrative perspectives (Fig. 1) are relevant:

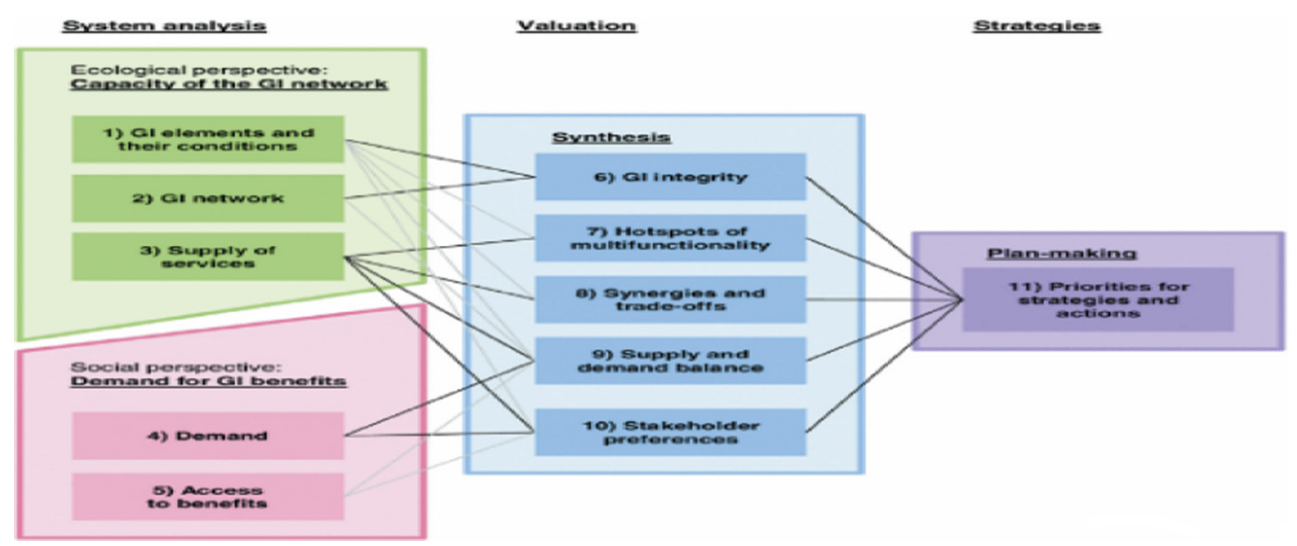

Figure 1: Conceptual framework for assessment of GI multi-functionality (source: [13]). 


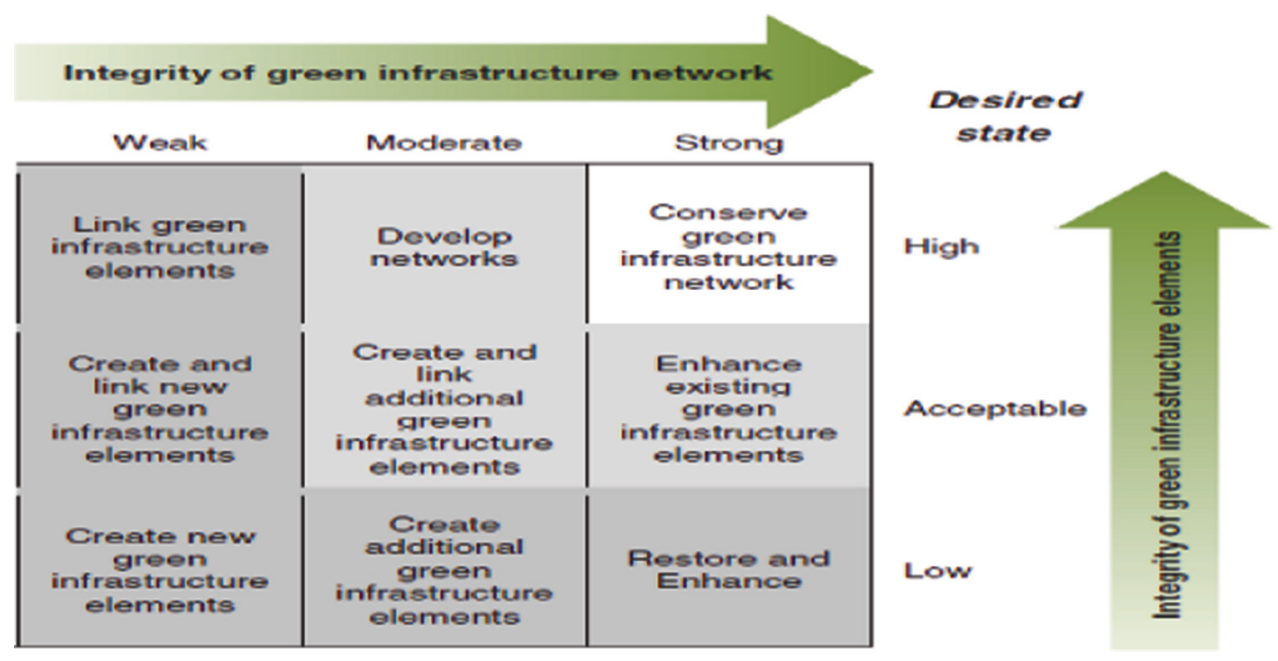

Figure 2: Decision support system based on the connectivity of the green network and the quality of its elements (as adapted in source: [13]).

From a planning, decision support system, alignment and integration perspective through transdisciplinary planning processes in enhancing mainstreaming of GI, the content of Fig. 2 should be considered. It provides for a desired state between integrity of GI networks versus integrity of GI elements.

\section{COVENTIONAL SPATIAL, INFRASTRUCTURE PLANNING AND DEVELOPMENT IMPLICATIONS AND PRACTICES}

The development of urban and rural form includes broader spatial planning processes consisting of environmental, spatial and transportation planning processes and frameworks. It provides for the consideration of locational impacts, topography, soil conditions, accessibility and environmental impacts as basis for spatial form.

Conventional infrastructure (CI) design, planning and development includes the provision of bulk and internal infrastructure systems of water provision, sewerage (sanitation), electricity systems, storm water, road and movement networks, solid waste collection and disposal sites. CI standards are taken into consideration during the layout and planning of township development. (Refer to [14] for the underlying principles, layout and design and engineering standards for CI planning.)

The challenge in sustainable spatial planning and development is to integrate the concepts and approaches as provided for in GI, ES and CI in promoting resilience and sustainability in a transdisciplinary coalition between professions. Theory and practice sometimes illustrates some desire for inclusiveness in aligning spatial and transportation planning, layout and design, engineering services provision and related services. This becomes even more complicated when the philosophy and practice of GI, ES and CI and technology in spatial form and development is considered. Land use schemes, building codes and regulations applicable to conventional planning and development are not optimally aligned in a transdisciplinary way to enhance mainstreaming of green planning approaches and practices. 
Spatial, urban and transportation planning is facilitated by specific professions in the built environment through policies, legislative provisions and practices as provided for in land use management systems, planning instruments and professions (work reservation) regulating certain professions. Existing and future planning and development processes need to be aligned to principles such as GI application and ES promotion that focus on transdisciplinary thinking, integration and transformation. The question remains as to how to articulate existing planning practices to support urban resilience and sustainability through improved alignment and integration.

The articulation of GI and ES approaches in spatial and transportation planning and development is independent of the development phase within any spatial system. In new urban development the introduction of GI in ES need to be the transformation interface of all planning and development processes, actions and decisions [3]. The challenge is to transform and integrate planning practices from a process, practice and standard perspective. Table 2 shows the status quo complexities in terms of planning instruments that need to be aligned through transdisciplinary planning practices.

Spatial and urban system and form is complex and dynamic. It includes challenges such as densification, redevelopment and renewal initiatives that are market driven. It pivots on the need to apply change management that will ensure optimization and redefining of the existing processes supported by various professionals and disciplines. It includes revisiting of existing codes of practice [14] to transform CI to be optimally aligned to GI in enhancing ES through transdisciplinary enablement. Shifting boundaries guiding training, processes, practices and professionalism in planning within the built environment (that is in essence technocratic in nature) is thus fundamental. It depends on the integration and alignment of realties through a paradigm shift to enhance and integrate challenges in planning and development.

Statutory planning and land management pivots on instruments that are organized and regulated through land use schemes and its supporting planning frameworks [15]. These processes are based on land use rights (primary, secondary, tertiary and uses not provided for in certain areas), zoning, density, coverage, building lines and height restrictions of buildings. Supplementary conditions (floor area ratio (FAR), parking provision, greening requirements,

Table 2: Complexities to be aligned between planning instruments, application of GI and ES.

\begin{tabular}{lll}
\hline Spatial planning & Transportation planning & Environmental planning \\
\hline $\begin{array}{l}\text { Spatial development and } \\
\text { strategies }\end{array}$ & $\begin{array}{l}\text { Transportation development } \\
\text { strategies }\end{array}$ & $\begin{array}{l}\text { Environmental management } \\
\text { strategies }\end{array}$ \\
$\begin{array}{l}\text { Spatial development } \\
\text { frameworks }\end{array}$ & $\begin{array}{l}\text { Integrated transportation } \\
\text { plans }\end{array}$ & $\begin{array}{l}\text { Environmental frameworks } \\
\text { Neighborhood plans }\end{array}$ \\
$\begin{array}{l}\text { Precinct plans } \\
\text { Land use schemes }\end{array}$ & Corridor development plans & Manvironmental assessments \\
& Public transport plans & $\begin{array}{l}\text { Environmental impact } \\
\text { assessments }\end{array}$ \\
Site development plans & Traffic impact studies & EIA site development plans \\
\hline
\end{tabular}

Source: Own construction, 2017. 
etc.) are linked to certain stands or portions of land. In spatial and statutory planning, these land uses (existing and future) determine the standards and level of infrastructure and services to be provided in terms of CI. In this, the application of new technology fulfils an important role in enhancing a GI focus in planning and design.

Many papers deal with this challenge through process, procedure, content and format analysis describing and defining the roles and focuses of different professions and/or disciplines. However, the integration between CI- and GI-orientated approaches requires a dualism between all planning and development disciplines. This relationship is even more complex in cases of urban renewal and/or regeneration especially where replacement and upgrading of services are a consideration. It also involves the national, regional, strategic and spatial planning reality and practices [16].

\section{CONVENTIONAL INFRASTRUCTURE AND GREEN PLANNING INFRASTRUCTURE IMPLICATIONS}

\subsection{Alignment and interface between planning and development}

Schoeman [17] demonstrates the role of transportation in urban form and systems. It implies that the interface between planning and development related to urban spaces (the grey and green components) is a function of development forces and approaches applied over many years. It is impacted upon by factors such as locational considerations, increase in demand for housing and services and need for accessibility. Urban spaces develop either spontaneously or for specific functions and result in different layout and design forms inclusive of land use in transportation systems [18].

Existing spatial and urban form represents a reality that needs specific intervention to integrate CI and GI development. It includes the application of terminology such as "greening the grey", "urban resilience", "green urbanism" etc. being used in different ways by researchers working in related disciplines.

From the literature, it is evident that the concept of 'green planning' is often used interchangeably by some authors that is indicative of the need to promote and enhance the interface/alignment in spatial, urban and transportation planning. Development of spatial and environmental systems through GI-orientated planning requires transdisciplinary interventions. This challenge, however, is much more complicated than the arguments and/or justifications contained in specialized fields focussing on certain components in GI and ES application. Planning in general should be more inclusionary than the present exclusionary approaches underpinning research and practice (refer to Table 2).

Regional and urban form develop through specific phases of planning and development in terms of transformation. In this process, the grey environment is created as a result of historical forces and decision-making which embrace CI planning and development on a disciplinary and in inter-disciplinary level. This implies that the definition of the grey environment and the goal of transformation through applying GI principles and technology application should be understood in the context of the need to integrate the domain of planning. In essence, it will require a paradigm shift in training and practice application by related disciplines.

Figure 3 shows a simplified presentation of the complexities consisting of governance, energy flows, infrastructure form and socioeconomic dynamics (thus CI orientated and the opportunity for GI application) present in spatial systems. 


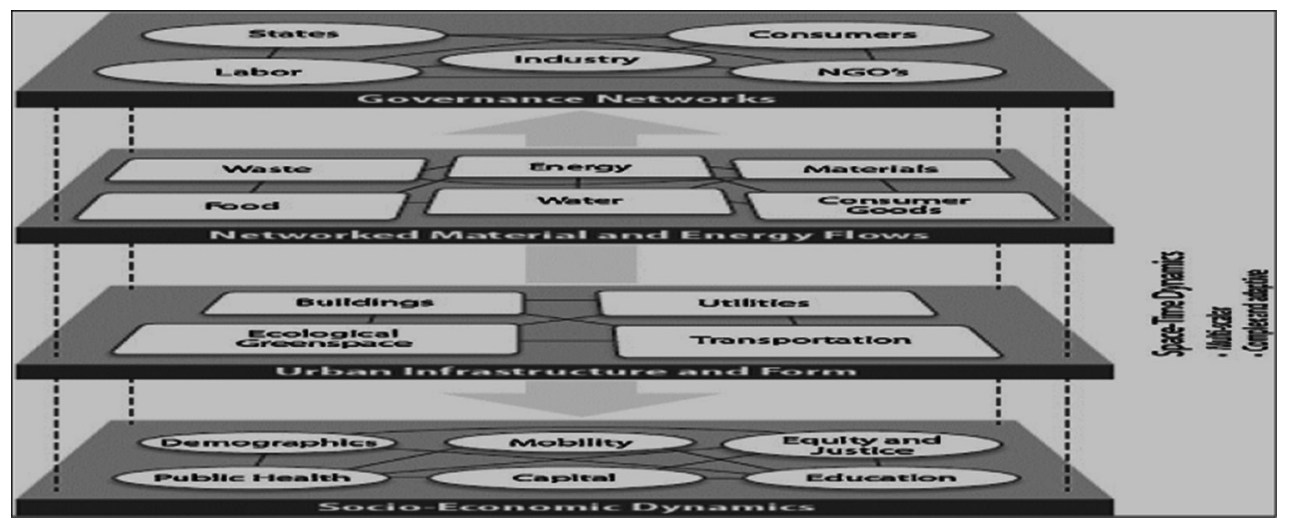

Figure 3: A simplified conceptual schematic interpretation of considerations in urban-related spatial systems (source: Meerow et al. [19]).

\subsection{Implications of the role of spatial and statutory planning in promoting GI mainstreaming through transdisciplinary planning approaches}

This section contains an overview of the background to conventional spatial and infrastructure planning and development. In terms of the theme of this article, the implications and role of statutory planning and GI mainstreaming need to be considered.

Statutory planning and development contributions (also known as development charges or capital contributions) consist of a capital levy/impact fee or levy by municipalities in terms of bulk engineering service (CI) provision. The focus is to recover the actual costs of external infrastructure capacity required to accommodate the additional impact of demand on engineering services [20]. Graham and Berrisford state that there is a tendency for developers to provide 'green' infrastructure but that such developers must still contribute to conventional development contributions. At present, the focus in GI-related practices in development contributions is separate from infrastructure service provision such as water, sewerage, storm water systems, road networks and energy generation (solar etc.) which traditionally forms part of CI service provision. Development contributions are being levied within municipalities in terms of existing policies, legislative frameworks and instruments guiding spatial planning and land use management and are predominantly CI orientated.

The need thus exists that the interface between CI and GI should be redefined. The roles and relationships between professionals, developers and decision-makers should include an integrated focus (transdisciplinary level) in terms of revised codes of practice and standards to accommodate new policies, technology and practice (GI orientated) in determining development contributions [3]. It should promote transdisciplinary practices with the focus on enhancing resilience and sustainability within all spatial systems. It implies the integration of planning processes and plans through application of appropriate GI practice and technology in both development and redevelopment of urban spaces inclusive of its supporting transportation systems. The emphasis should be on transdisciplinary integration of the processes underlying all policies, practice and process.

From Fig. 4, it can be deduced that the internal structure of urban spatial systems is not homogeneous and the need exists for improved spatial integration, densification, development of public transportation systems and alignment. The core focus is the application of transdisciplinary linkages involving all role players, professionals and disciplines. It implies 

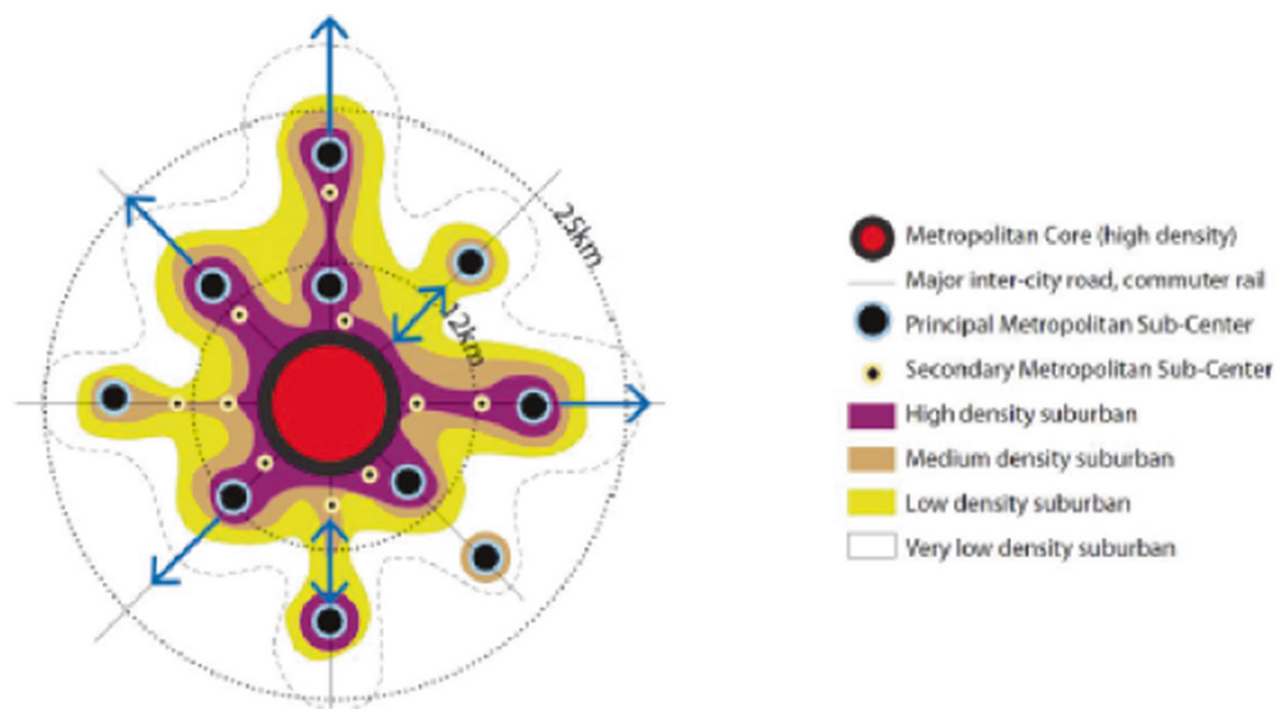

Figure 4: Theory underpinning traditional polycentric urban form model (source: Urban Morphology Institute as contained in [21]).

(within the existing and future urban form) identification of priority spatial development areas (zones) for preferred application of GI technology and approaches.

The spatial context as included in Fig. 5 demonstrates the considerations to be followed in aligning GI, spatial and transportation planning and mainstreaming of the concepts dealt with in this article from a transdisciplinary perspective.

Initiative/interest area

How does $\mathrm{Cl}$ relate

Potential to contribute to BAP

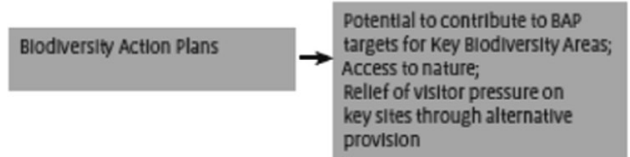
provision
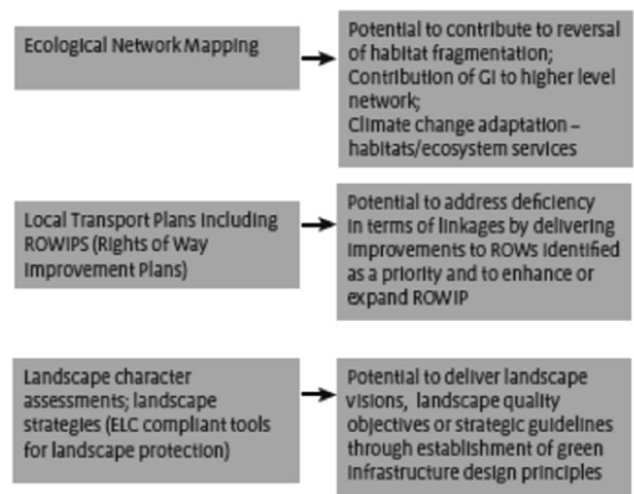

Initiative/interest area How does $\mathrm{CI}$ relate

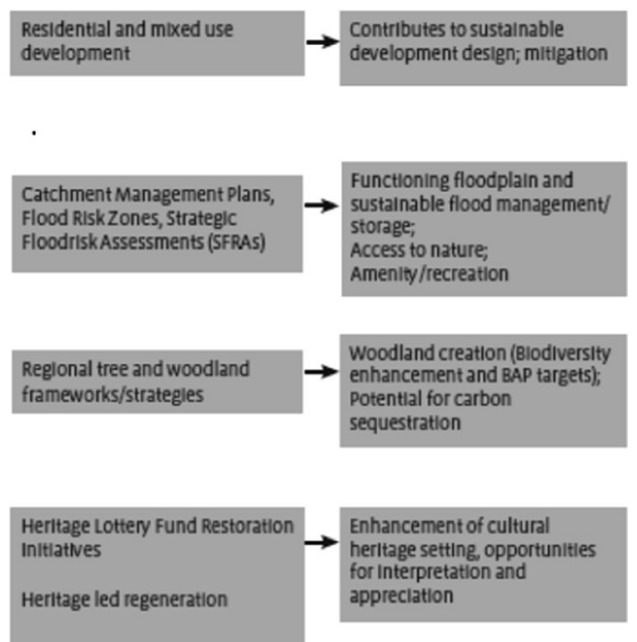

Figure 5: Alignment of planning instruments and its relationship to GI (source: [22]). 


\section{INCENTIVES IN POLICY FORMULATION FOR PROMOTION OF GREEN INFRASTRUCTURE APPLICATION IN PLANNING INSTRUMENTS}

The use of incentives to promote GI in integrated spatial development and related goals and objectives is accommodated in different ways through statutory planning instruments guiding spatial, land use and transportation system planning and development. The standard practice in statutory planning [20] is to calculate development contributions based on use of capacity in existing infrastructure systems and is calculated in terms of proportional use (equivalent erven) in CI infrastructure and service systems. The objective, however, should be to optimize transdisciplinary use of GI in ES promotion within infrastructure provision and utilization in urban system development and/or urban regeneration. It will require differentiation in infrastructure policies for bulk and internal infrastructure systems, planning and practices in all spatial systems.

It implies the identification of GI incentive infrastructure zones within the existing and future urban form (Fig. 4). The alignment of CI and GI as an incentive in spatial development needs to be professionally facilitated. Environmental, spatial, transportation and development considerations such as promotion of densification and spatial integration requires specific strategic and implementation mechanisms. It includes the identification of spatial zones or areas where GI incentives linked to infrastructure services will be applicable. Such policies may include lower property rates and service tariffs for GI promotion in such identified incentive areas. The focus will be on CI and GI alignment. Enhancement of public transport, accessibility, optimal use of natural services and amenities should be the core focus.

The identification of GI incentive zones needs to focus on spatial, land use, transportation integration (inclusive of corridors and nodal development) and supportive infrastructure provision systems (CI and GI based). Such areas should promote self-sustaining principles through optimizing the interface between CI and GI in development. It will promote ES sustainability. It needs to be included in strategy formulation during spatial development framework and transportation plan formulation. In the case of transportation, such GI incentive zones should be located along movement corridors as to deal with impacts such as air quality, traffic congestion and parking. It will cut down on private trip generation, reduced traffic flow and improved traffic distribution that will enhance ES promotion.

Performance assessment, should, however, be supported through the development of GI evaluation tools [23] in measuring successes and failures in integration and alignment. It implies that new GI assessment benchmarking needs to be developed inclusive of strategic, spatial, land use and transportation considerations and application of CI and GI best practices, development realities and related implications.

In supporting this objective, the development of modelling tools to predict possible outcomes to optimize transdisciplinary planning processes and to inform decision-making by planning authorities, needs to be developed.

\section{CONCLUSIONS}

From the reasoning and line of argument as contained in this article, it is evident that practitioners should reinvent spatial and transportation planning in terms of application of transdisciplinary approaches, teamwork and involvement. It may imply development of integrated planning practices related to CI, GI and ES alignment and enhancement through formulation of an Integrated Ecosystem Development Plan (IESDP). It should not only be process and stakeholder orientated but will have to review existing practices in terms of promotion of transdisciplinary processes and practices. This will integrate the role of professionals, 
stakeholders and decision-makers in the planning and development cycle. GI should not be viewed as an 'add on' after the grey spaces have been planned, designed and constructed. GI is about much more than the concept of 'greening' the 'grey'.

\section{REFERENCES}

[1] Campbell, S., Green cities, growing cities, just cities. Urban planning and the contradictions of sustainable development. APA Journal, 62(3), pp. 296-312, 1996. DOI: 10.1177/0739456X8400400103.

[2] United Nations Global Report on Human Settlements-Planning Sustainable Cities, United Nations Human Settlements Programme, pp. 1-306, available at https://unhabitat.org/ global-report-on-human-settlements-2009-planning-sustainable-cities, 2009 (accessed 8 October 2017).

[3] Schoeman, C.B., Theoretical perspectives on resilience and sustainability in transportation and spatial planning. WIT SPD Conference, Bristol, 2017.

[4] Cortinovis, C. \& Geneletti, D., Ecosystem services in urban plans: what is there, and what is still needed for better decisions. Land Use Policy, 70, pp. 298-312, 2018. DOI: 10.1016/j.landusepol.2017.10.017.

[5] Cilliers, E.J. \& Cilliers, S.S., Planning for Green Infrastructure: Options for South Africa, South African Cities Network: Johannesburg, 2016. ISBN: 978-0-620-72315-2.

[6] Mell, I.C., Aligning fragmented planning structures through green infrastructure approach to urban development in the UK and USA. Urban Forestry and Urban Greening, 13(4), pp. 612-620, 2014. DOI: 10.1016/j.ufug.2014.07.007.

[7] Ranjha, S., Brief for GSDR - 2016 Update. Green infrastructure: planning for sustainable and resilient urban environment. DLGS-IOER-TU Dresden, Germany, 2016.

[8] Sinnett, D., Jerome, G., Smith, N., Burgess, S. \& Mortlock, R., Raising the standard: developing a benchmark for green infrastructure. International Journal for Sustainable Development Planning, 13(2), pp.226-236, 2018. DOI: 10.2495/SDP-V13-N2-226-236.

[9] United States Environmental Protection Agency (EPA), What is Green Infrastructure? Overcoming Barriers to Green Infrastructure, available at www.epa.gov/green-infrastructure/what, 2017 (accessed 30 August 2017).

[10] Centre for Leadership in Global Sustainability, VirginiaTech and NARC. Greening the Grey: An Institutional Analysis of Green Infrastructure for Sustainable Development in the US, available at http://cligs.vt.edu/greening-the-grey-green-infrastructure-forsustainable-development/, 2013 (accessed 20 October 2017).

[11] European Commission, Green Infrastructure, available at http://eceuropa.eu/environment/nature/ecosystems/index_en.htm, 2016 (accessed 4 October 2017).

[12] Albert, C. \& Von Haaren, C., Implications of applying the green infrastructure concept in landscape planning for the ecosystem services in peri-urban areas: an expert survey and case study. Planning Practice and Research, 32(3), pp. 227-242, 2014. DOI: 10.1080/13549839.2011.631993.

[13] Hansen, R. \& Pauleit, S., From multifunctionality to multiple ecosystem services? A conceptual framework for multifunctionality in green infrastructure planning for urban areas. AMBIO, 43(4), pp. 416-529, 2014. DOI: 10.1007/s13280-014-0502-2.

[14] CSIR Building and Construction Technology, Human Settlements Planning and Design, Vol. 1 and 2, available at https://www.csir.co.za/sites/default/files/Documents/ Red_book voll.pdf and https://www.csir.co.za/sites/default/files/Documents/Red_ BookVol2.pdf 
[15] Nel, V., A better zoning system for South Africa? Land Policy, 55, pp. 257-264, 2016. DOI: 10.1016/j.landusepol.2016.04.007.

[16] Giordano, T., Multilevel integrated planning and greening of public infrastructure in South Africa. Conference Proceedings of ART-Dev. 2013-01, available at www.tandfonline.com/doi/abs/10.1080/14649357.2014.963651, 2013 (accessed 10 October 2017).

[17] Schoeman, C.B., International perspectives on transportation and urban form integration. International Journal of Transport Development and Integration, 1, pp. 1-15, 2017. DOI: 10.2495/TDI-V1-N1-1-15.

[18] Schoeman, C.B. (ed.), Land Use Management and Transportation Planning, WIT Press: Southampton, Boston.

[19] Meerow, S., Newell, J. \& Stults, M., Defining urban resilience: a review. Landscape and Urban Planning, 147, p. 38, 2016. DOI: 10.1016/j.landurbplan.2015.11.011.

[20] Graham, N. \& Berrisford, S. Development charges in South Africa: current thinking and areas of contestation. IMESA Conference, 2015, East London, South Africa.

[21] City of Johannesburg Metropolitan Municipality, Spatial Development Framework 2040. Department of Development Planning: City of Johannesburg, pp. 1-171, 2016.

[22] Natural England, Green Infrastructure Guidance. NE176 2009, available at http://naturalengland.org.uk, 2009 (accessed 17 October 2017).

[23] Natural England, Green Infrastructure Valuation Tools Assessment. Natural England Commissioned Report NECR 126, available at www.naturalengland.org.uk, 2013 (accessed 17 October 2017). 